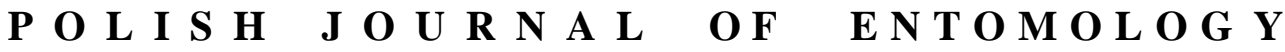

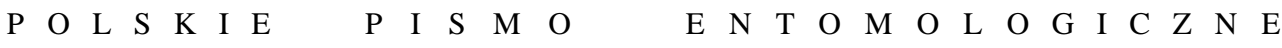

VOL. 86: 275-291

Lublin

30 September 2017

DOI: $10.1515 /$ pjen-2017-0016

\section{A new species Phlebopterum planicapitis from Madagascar (Hemiptera: Fulgoromorpha: Flatidae)}

\author{
DARIUSZ ŚWIERCZEWSKI ${ }^{1 *}$, ADAM STROIŃSKI $^{2}$ \\ ${ }^{1}$ Department of Biology and Nature Conservation, Jan Długosz University, Al. Armii \\ Krajowej 13/15, 42-201 Częstochowa, Poland \\ ${ }^{2}$ Museum and Institute of Zoology PAS, Wilcza 64, 00-679 Warszawa, Poland
}

\begin{abstract}
A new planthopper species of the family Flatidae Phlebopterum planicapitis sp. $\mathrm{n}$. endemic to Madagascar is described and illustrated. The species is limited to the north-western part of the island and is associated with coastal mangroves and riverside vegetation. A key to all the Phlebopterum species known from Madagascar is provided.
\end{abstract}

KEY WORDS: Fulgoromorpha, Flatidae, new species, biodiversity, Madagascar.

\section{INTRODUCTION}

Madagascar is considered to be one of the eight most important global biodiversity hotspots (MYERS et al. 2000). Owing to its spectacular geological history (STOREY et al. 1995), an incredible wealth of biodiversity has evolved there, with exceptional biota and thousands of species that can be found nowhere else on Earth (MCNEELY et al. 1990, GANZHORN et al. 2001).

Flatidae constitutes one of the largest families within planthoppers (Fulgoromorpha, Hemiptera) with 1429 described species in 300 genera, covering 2 subfamilies: Flatinae SPINOLA, 1839 and Flatoidinae MELICHAR, 1901 (BOURGOIN 2017). These phytophagous insects are found on all continents but are especially common and abundant in the tropics (O'BRIEN 2002). The Flatidae fauna of Madagascar includes a total of 21 genera with 50

\footnotetext{
* Corresponding author: dswier@ajd.czest.pl
} 
species of Flatinae and 11 genera with 37 species of Flatoidinae (ŚWIERCZEWSKI \& StroiŃSKi 2013, MĄKOL et al. 2014, STROIŃSKI \& ŚWIERCZEWSKI 2014a, 2014b, ŚWIERCZEWSKI \& STROIŃSKI 2015a, 2015b, ŚWIERCZEWSKI et al. 2016).

The Afrotropical flatid genus Phlebopterum STÅL, 1854 covers three species confined to continental Africa: P. solitum (WALKER, 1851), P. angulinum SCHMIDT, 1912 and $P$. seydeli (LALLEMAND, 1931), together with the following ones known only from Madagascar: P. angulatum MeliChAR, 1902, Phlebopterum viridis MELICHAR, 1902 and $P$. tapiae ŚWIERCZEWSKI et STROIŃSKI, 2012.

Below, a new species of the genus Phlebopterum from north-western Madagascar is described and illustrated.

\section{MATERIALS AND METHODS}

The specimens studied in the course of this work are deposited in the following collections: MNHN - Muséum national d'Histoire naturelle, Paris (France); CAS California Academy of Sciences, Department of Entomology, San Francisco (USA).

The abdomens of the specimens examined were removed and cleared for $30 \mathrm{~min}$. in warm $\left(50^{\circ} \mathrm{C}\right) 10 \% \mathrm{KOH}$ with a few drops of chlorazol black to stain the genital structures based on the method introduced by CARAYON (1969) and BOURGOIN (1993). Dissections and cleaning of genital structures were performed in distilled water. Final observations and drawings were done in glycerine using a camera lucida attached to a light microscope. All colour images were taken using a Leica MZ 16 stereomicroscope equipped with an IC 3D digital camera. The final images were produced using Helicon Focus and Adobe Photoshop CS3 software. The SEM photographs of uncoated specimens were taken in the Laboratory of Scanning Microscopy, MIZ PAS (Warsaw), using a HITACHI S-3400N scanning electron microscope under low vacuum conditions.

The following measurements made with an ocular micrometer, ratios and abbreviations are used in this study: Total length - measured (in dorsal view) from apex of head crown to apex of tegmina; $\mathrm{A} / \mathrm{B}$ - width of vertex measured at anterior margin/length of vertex measured at midline; C/E - width of frons between eyes/length of frons at midline; $\mathrm{D} / \mathrm{E}$ - maximum width of frons/length of frons at midline; F/B - length of pronotum at midline/length of vertex at midline; $\mathrm{G} / \mathrm{F}$ - length of mesonotum/length of pronotum at midline; $\mathrm{G} / \mathrm{B}+\mathrm{F}$ - length of mesonotum/cumulative length of vertex and pronotum at midline; G/H - length of mesonotum at midline/width of mesonotum between lateral angles; $\mathrm{I} / \mathrm{J}$ - length of tegmen measured from base to apical margin in median portion/width of tegmen measured from apex of clavus to anterior margin. 
The nomenclature of forewing (tegmen) veins follows the interpretation proposed by BOURGOIN et al. (2015). Antennal structures are named in accordance with STROIŃSKI et al. (2011). The terminology of the genitalia follows BOURGOIN (1988) and BOURGOIN \& HUANG (1990) for the male, and BouRGoIN (1993) for the female.

\section{RESULTS}

Order Hemiptera LinNAEUs, 1758

Suborder Fulgoromorpha EVANS, 1946

Superfamily Fulgoroidea LATREILLE, 1810

Family Flatidae SPINOLA, 1839

Subfamily Flatinae SPINOLA, 1839

Tribe Sisciini MELICHAR, 1923

Genus Phlebopterum STÅL, 1854

\section{Phlebopterum planicapitis sp. $\mathbf{n}$.}

(Figs 1-39)

\section{Diagnosis}

Phlebopterum planicapitis sp. n. differs from Phlebopterum tapiae in the following characters: frons, in dorsal view, with huge crown (frons, in dorsal view, with small protrusion in $P$. tapiae); male genitalia - stylus not incised, aedeagus with dorsal and lateral lobes (stylus deeply incised, aedeagus without dorsal and lateral lobes in P. tapiae); female genitalia - gonoplac rounded, diverticulum ductus short, with round, apical bulb (gonoplac triangular, diverticulum ductus long, with elongately widened apical part in P. tapiae).

\section{Material examined}

Holotype, $\widehat{\partial}$ (label inscriptions under the specimen given verbatim in square brackets): [12/XI/2005 region Mahajanga Antrema, mangrove], [Museum Paris Madagascar 2005 Bourgoin, Ouvrard, Attié, Soulier-Perkins] - (MNHN).

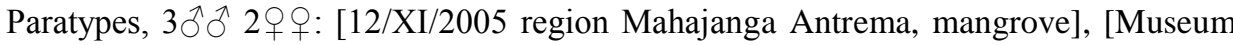
Paris Madagascar 2005 Bourgoin, Ouvrard, Attié, SouliER-PERKINS] - $1 \hat{\varnothing}$ (MNHN); [14/XI/2005 bd rivière RN4 Mahajanga á Maevatanana, $184 \mathrm{~m}$ 16²45.974'S 4701.982'E], [Museum Paris Madagascar 2005 Bourgoin, Ouvrard, Attié, SOULIER-PERKINS], [handwritten: Majunga $\rightarrow$ ? Maevata 14/xi/2005 MA 12x3] - 1ठ $(\mathrm{MNHN})$; [10/XI/2005 région Mahajanga Antrema, $15^{\circ} 42.727^{\prime} \mathrm{S}, 46^{\circ} 12.707^{\prime} \mathrm{E}$ ], [route phare à village sur Matrobe 
30m], [Museum Paris Madagascar 2005 Bourgoin, Ouvrard, Attié, SOULIER-PERKINS] - 1 q (MNHN); [11/XI/2005 région Mahajanga Antrema, forêt, 54 m 15 42.444'S, 46²10.184'E], [Museum Paris Madagascar 2005 Bourgoin, Ouvrard, Attié, SouliER-PERKINS] - 1 q (MNHN); [MADAGASCAR: Majunga Ambovomamy Belambo $20 \mathrm{~km} \mathrm{NW}$ of Port Berger 17-25 July $20071^{\circ} 27.07^{\prime} S, 47^{\circ} 36.80^{\prime} E$ ], [California Acad of Sciences coll: R. HARIN'HALA, M. IRWIN, F. PARKER, malaise, secondary growth on white sand elev $33 \mathrm{~m}$ MG-33-29], [CASLOT 044583] - 1 ठิ (CAS).

\section{Description}

Body slender. Total length 6.8-7.4 mm. Head and thorax brownish-red; tegmina ochraceous with greenish tinge and brownish veins, costal, apical and claval margin of tegmen dark brown, clavus brownish-red; legs yellowish, fore and middle tibiae mottled (Figs 1-5).

Head with compound eyes (in dorsal view) about as wide as thorax (Figs 2, 4, 6). Vertex transverse, separated from frons, distinctly wider than long at midline, hourglass shape; anterior margin wider than posterior margin, in form of small ridge deeply incised medially, proportion $\mathrm{A} / \mathrm{B}=26.70-35.00$; posterior margin elevated, laterally covered by pronotum (Figs 4, 6-7); lateral margins as ridges, almost straight and subparallel; disc of vertex without carinae (Figs 6-7).

Frons (Figs 1-9) about as long as wide, widest between lower parts of compound eyes, proportion $\mathrm{C} / \mathrm{E}=0.81-0.83$, proportion $\mathrm{D} / \mathrm{E}=0.83-0.90$; frons (in dorsal view) with huge and wide crown; lateral margins of crown almost straight, anterior margin strongly arcuate; apex of crown (in lateral view) distinctly elevated (Figs 1, 5, 8). Frons with all margins well carinate and elevated, anterior margin strongly arcuate, lateral margins almost straight and parallel in upper part, with triangular protrusions at lower part of compound eyes, converging below to frontoclypeal suture. Disc of frons distinctly depressed, without carinae, distributed with small setae; ventro-median part of disc flattened and rugose (Figs $3,9)$.

Antennal segment II (pedicel) slightly longer than wide, wider at apex, sensory organs located at top of pedicel, in shallow depression, and partly at upper surface (Figs 10-11). Compound eyes oval with narrow callus at posterior margin, lateral ocelli present (Figs 1, $5,8)$.

Frontoclypeal suture weakly arcuate; clypeus without carinae, upper portion convex (Figs 3, 9). Rostrum reaching hind coxae; apical part shorter than the basal one. 

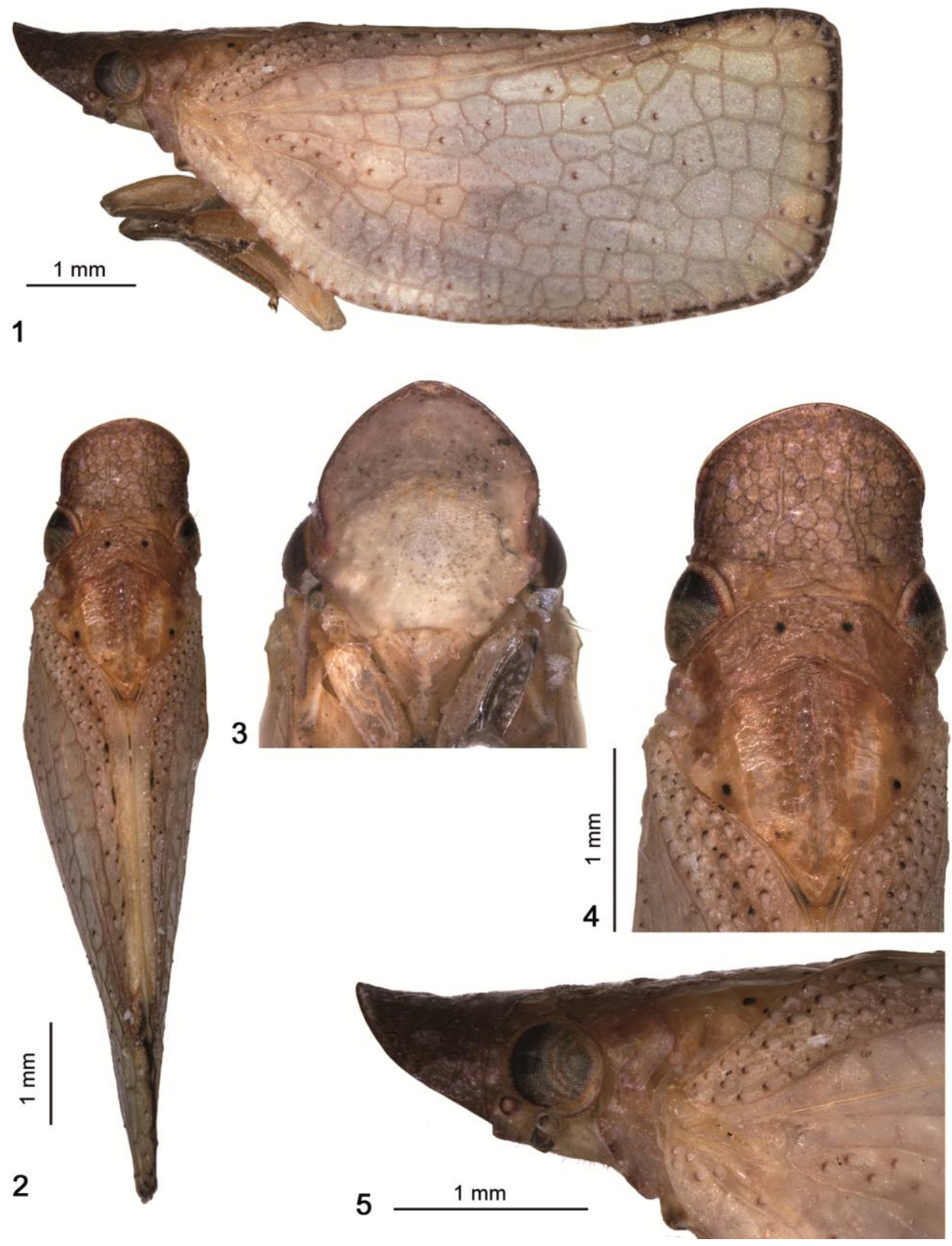

Figs 1-5. Phlebopterum planicapitis sp. n. 1 - habitus, lateral view; 2 - habitus, dorsal view; 3 - anterior part of body, frontal view; 4 - anterior part of body, dorsal view; 5 - anterior part of body, lateral view. 

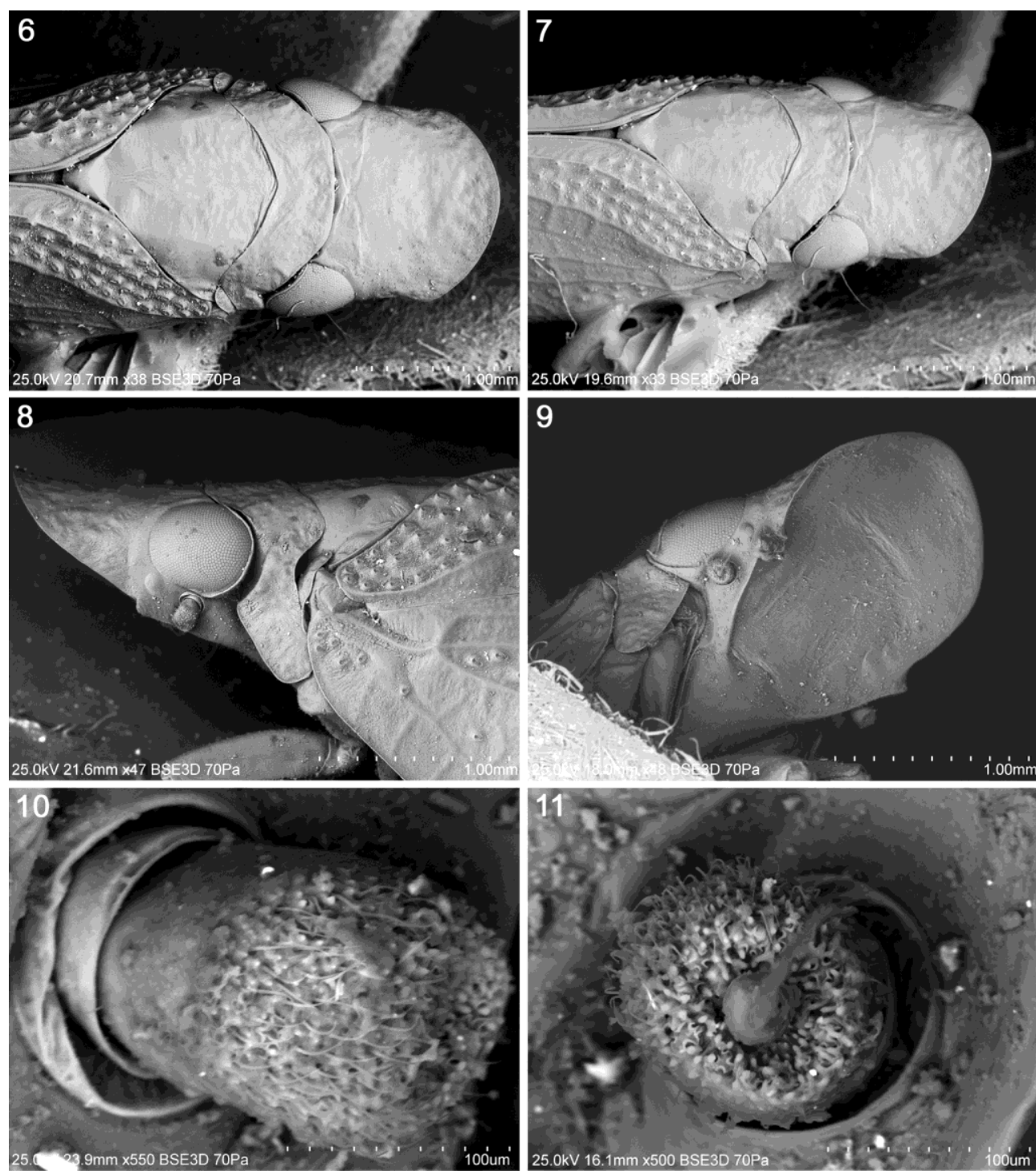

Figs 6-11. Phlebopterum planicapitis sp. n., SEM images. 6 - anterior part of body, dorsal view; 7 - anterior part of body, dorso-lateral view; 8 - anterior part of body, left lateral view; 9 - anterior part of body, ventro-lateral view; 10-11 - antenna. 

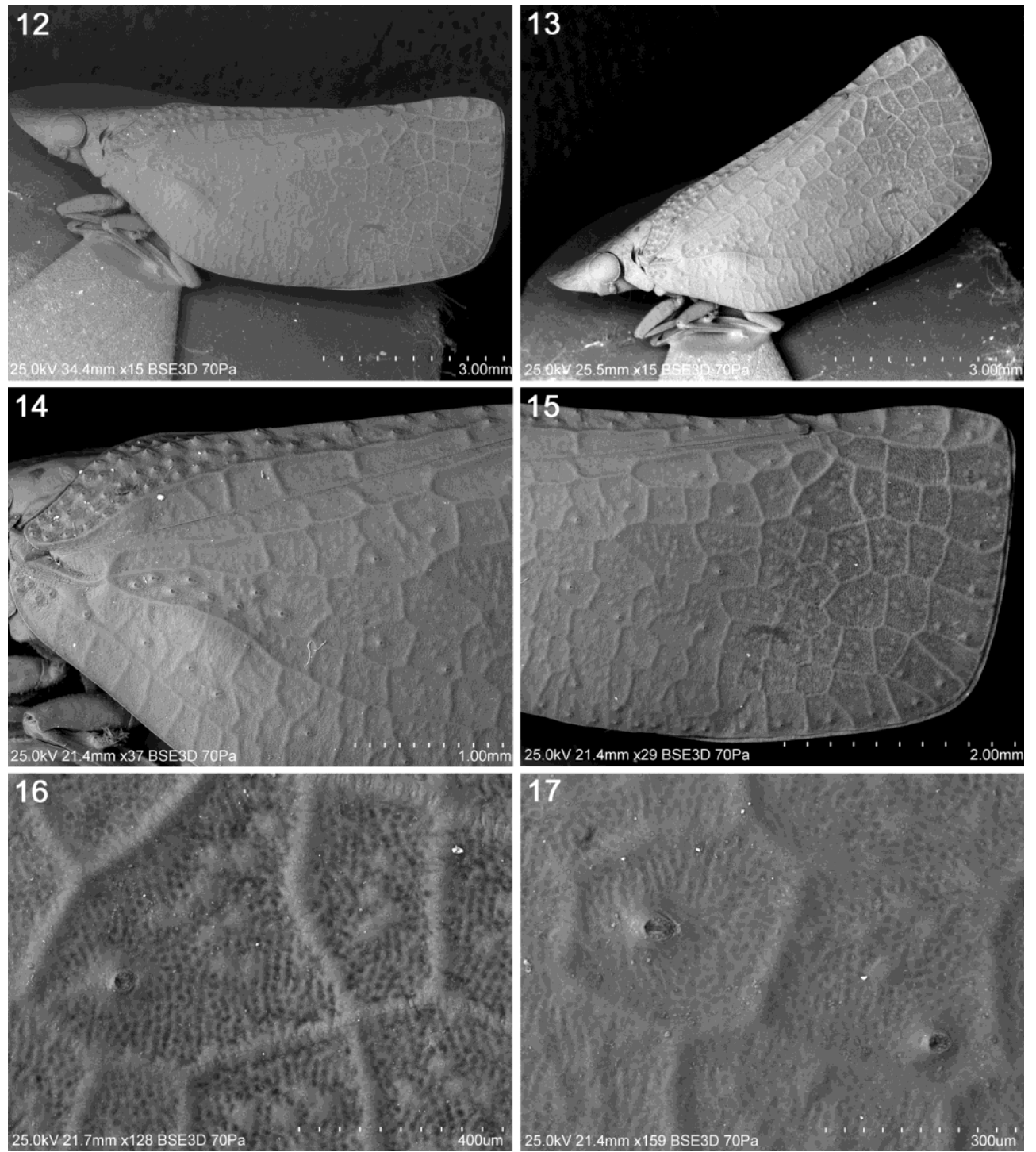

Figs 12-17. Phlebopterum planicapitis sp. n., tegmen, SEM images. 12-13 - general view; 14 - basal part; 15 - apical part; 16-17 - veins, sensory and secretory structures.

Thorax. Pronotum (Figs 2, 4, 6-7) distinctly longer at midline than vertex (proportion $\mathrm{F} / \mathrm{B}=9.00-12.50$ ); anterior margin arcuate, with median portion flattened; posterior margin distinctly concave; disc tuberculate, without carinae; postocular eminences in form of long crests. 
Mesonotum (Figs 2,7) deltoid, proportion $\mathrm{G} / \mathrm{F}=3.34-3.63, \mathrm{G} / \mathrm{B}+\mathrm{F}=3.03-3.35, \mathrm{G} / \mathrm{H}=$ 0.85-1.00; lateral angles placed about $1 / 3$ of the length of mesonotum at midline; disc of mesonotum laterally slightly depressed; scutellum triangular, elevated, with blunt apex.

Tegmen (Figs 1, 12-17) subrectangular, membranous, flat, surface smooth, proportion $\mathrm{I} / \mathrm{J}=2.29-2.56$; costal margin - about in $1 / 3$ arcuate, in $2 / 3$ straight, parallel to posterior margin; costal angle weakly rounded; apical margin straight; sutural angle almost right; postclaval sutural margin straight; costal area two times narrower than postcostal cell at the level of bulla, tapering apicad, with transverse veinlets, terminating before end of clavus; postcostal cell slightly tapering apicad, with sparse net of veinlets.

Basal cell about twice as long as wide. Longitudinal vein ScRA+RP arises as short common stem from basal cell; ScRA basally elevated, passing the top of bulla; RP in basal part obsolete, with first fork before ScRA fork. MP leaving basal cell with a long stalk, but shorter than CuA stalk, MP fork before RP fork. CuA diverging after the level of MP fork. Sc+RA ending with 4 terminals at costal margin, RP with 5 terminals at costal and apical margin, MP with 2 terminals at apical margin, CuA with 6 terminals at postclaval and apical margins.

Irregular net of numerous transverse veinlets starting from basal part of tegmen; nodal line absent, one apical line present, apical cells subrectangular; tubercles scattered on the whole tegmen with concentration alongside costal and apical margin, between basal part of RP and MP veins and on clavus. Claval veins slightly elevated, connected a little before end of clavus; transverse veinlets only between $\mathrm{CuP}$ and $\mathrm{PCu}$.

Femora shorter than tibiae; fore and middle tibiae flattened, with carinate margins; hind tibia arcuate with 2 lateral spines placed after midlength, row of 6 apical teeth in formula 2 (longer) +4 (shorter); basitarsomere as long as cumulative length of second and hind tarsomeres, with arcuate line of 7 apical teeth.

Male terminalia (Figs 18-23). Anal tube (in lateral view, Fig. 18) short and wide, with prolongation at postero-ventral angle oriented ventrad, anus placed before midlength. Anal tube (in dorsal view, Fig. 19) elongate, basal part almost the same width as apical part.

Pygofer (in lateral view, Fig. 18) higher than wide; dorsal part slightly narrower than ventral part, posterior margin arcuate. Postero-dorsal angle without process, bluntly rounded.

Genital style (in lateral view, in direct observation, Fig. 18) with ventral and posterior margin widely rounded, dorsal margin almost straight; postero-dorsal angle with short and blunt capitulum.

Phallic complex (Figs 20-23). Periandrium (Figs 20-21) elongate, basal part the same width as apical part, open dorsally almost to base, lateral split very shallow; dorsal part a little longer than ventral part with two apical process - longer oriented ventro-basad and shorter oriented ventrad; ventral part with single short apical process oriented ventrad and 
long and narrow median keel. Periandrium in median portion with three spines: short, upper spine oriented apicad placed on dorsal margin and additional two - short and long, placed on lateral surface, both oriented basad.
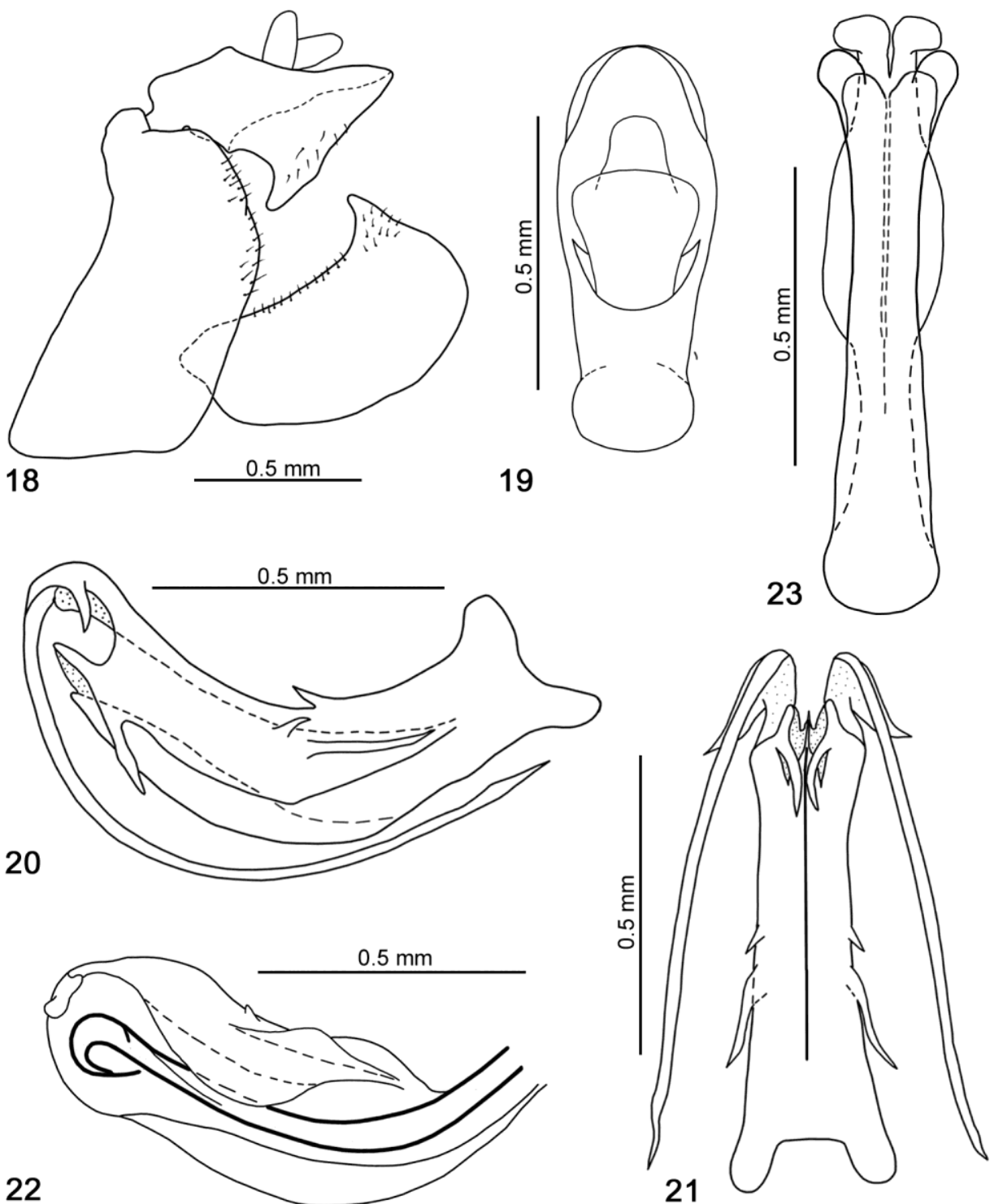

22

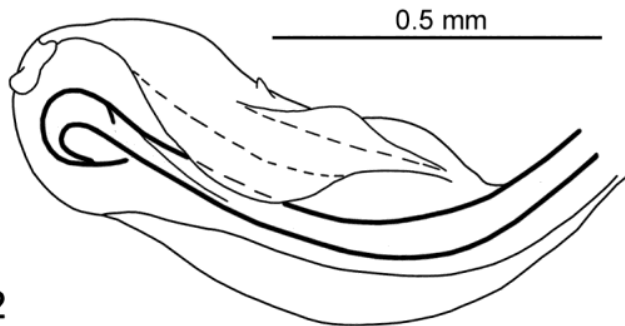

21

Figs 18-23. Phlebopterum planicapitis sp. n., male. 18 - genital capsule, lateral view; 19 anal tube, dorsal view; $\mathbf{2 0}$ - periandrium, lateral view; 21 - periandrium, ventral view; 22 aedeagus, lateral view; 23 - aedeagus, ventral view. 
Aedeagus s.s. (Figs 22-23) laterally flattened, with median split of 3/4 length; apical part with small rounded appendages, median part with dorsal and lateral lobes and short spine oriented dorso-apicad.

Female terminalia (Figs 24-29). Pregenital sternite (flattened, Fig. 24) subrectangular, covered with short setae, without separated lateral lobes; anterior margin well sclerotised, posterior margin sinuate with convex median portion.

Anal tube (in lateral view, Fig. 25) tapering apicad, reaching posterior margin of gonoplac, widest part at the level of base of anus; anus placed before midlength. Anal tube (in dorsal view, Fig. 26) elongately oval, massive, posterior margin with incision; anus placed before midlength.

Gonoplac unilobate, rounded (Fig. 27); posterior margin with single row of welldeveloped teeth; upper part to the level of teeth limit well sclerotised with long setae on dorsal and posterior margin; lower part smooth, with narrow, membranous fold only in distal part.

Gonapophysis VIII (Fig. 28) widely triangular, laterally flattened, slightly oblique with respect to longitudinal body axis; 5 large apical teeth on apical part of ventral margin; endogonocoxal process massive, about as long as gonaphophysis, tapering apicad, membranous with minute spiniferous microsculpture in basal part and large in apical part (Fig. 29).

Gonospiculum as in Figs 30-31.

Bursa copulatrix (Fig. 32) with single, elongately oval pouch placed vertically, membranous basal part thickened; cells with sclerotised plates on the whole surface (Fig. 33).

Spermatheca (Fig. 34) well developed; ductus receptaculi about three times longer than diverticulum ductus, ribbed, slightly widening apicad; diverticulum ductus smooth, with short basal tubular part and round, apical bulb.

\section{Etymology}

The specific epithet is a combination of the Latin words: planus (flat) and caput (head).

\section{Distribution}

North-western Madagascar; Antsiranana Province (Fig. 39).

\section{Key to the Phlebopterum species known from Madagascar}

1. Tegmen in the shape of a semicircle P. angulatum MELICHAR, 1902

- . Tegmen subrectangular

2. Male genital style with deep incision, V-shaped 
-. Male genital style without incision

3.

3. Male anal tube elongate and curved; apical part not wider than basal part

P. viridis MELICHAR, 1902

-. Male anal tube short and stout; apical part wider than basal part ..... P. planicapitis sp. n.

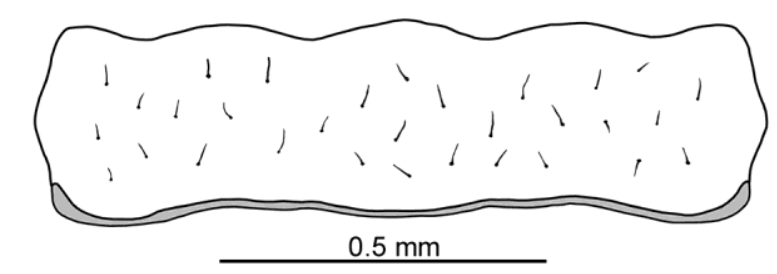

24

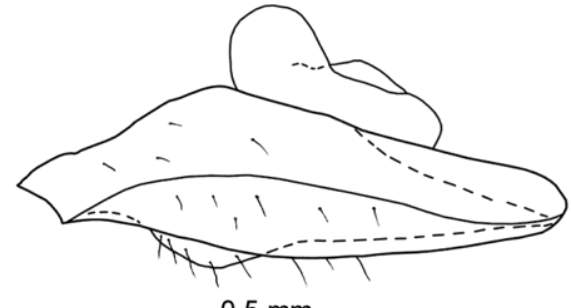

25

$0.5 \mathrm{~mm}$
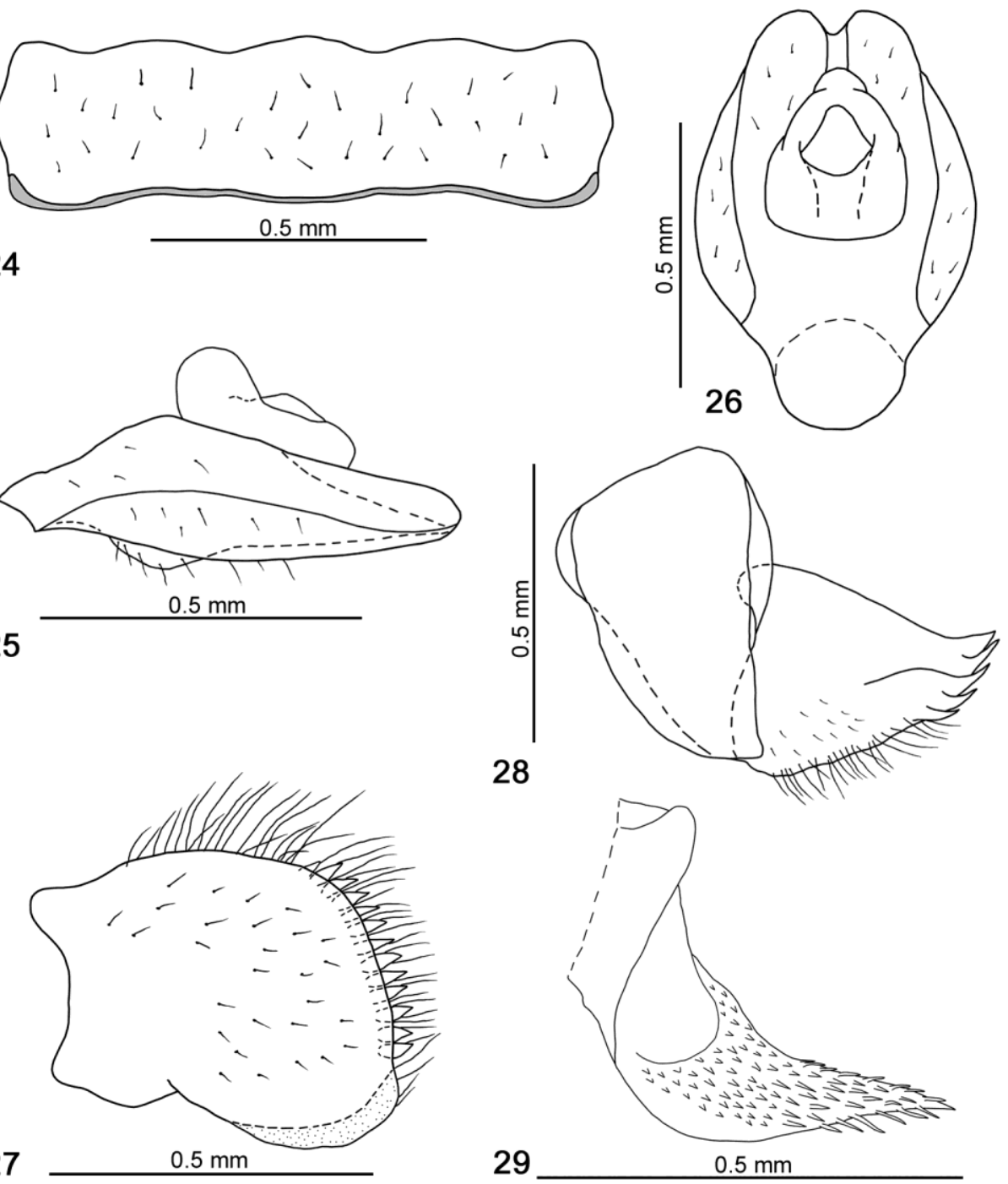

Figs 24-29. Phlebopterum planicapitis sp. n., female. 24 - pregenital sternite, flattened; 25 - anal tube, lateral view; 26 - anal tube, dorsal view; 27 - gonoplac, external view; 28 - gonapophysis VIII, dorso-lateral view; 29 - endogonocoxal process, external view. 

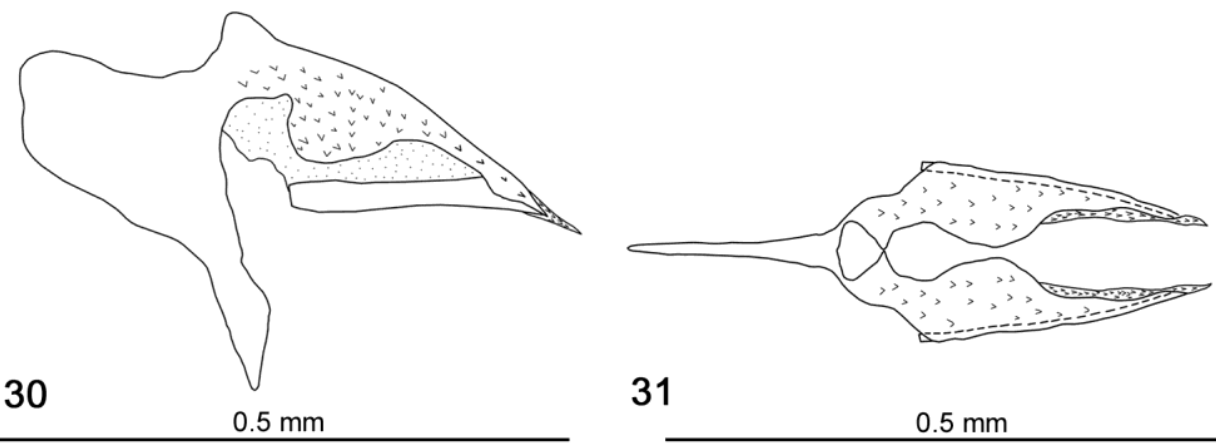

31

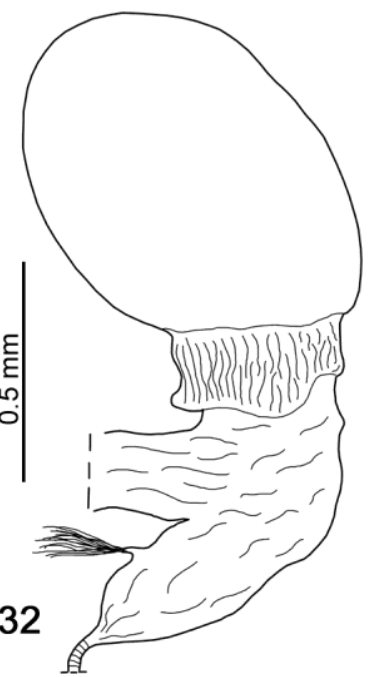

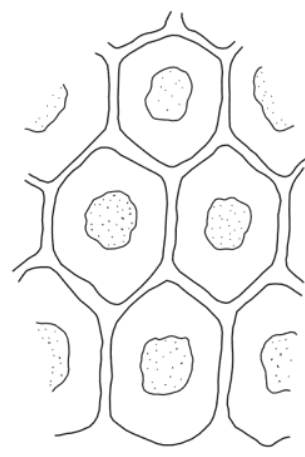

33

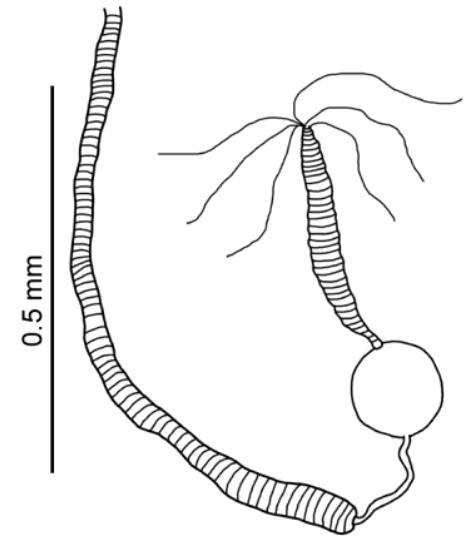

34

Figs 30-34. Phlebopterum planicapitis sp. n., female. 30 - gonapophyses IX and gonospiculum bridge, lateral view; 31 - same, dorsal view; 32 - bursa copulatrix, lateral view; 33 - bursa copulatrix, cells; 34 - spermatheca.

\section{DISCUSSION}

The Madagascan genus Phlebopterum is distributed across the whole island but the ranges of the particular species are limited to different regions and are associated with unique vegetation. $P$. tapiae is confined to central and southern Madagascar and is associated with an endemic and endangered formation known as tapia woodlands. $P$. viridis and $P$. angulatum are known from the northern and north-eastern part of the island and are both associated with eastern humid rainforests. In contrast, the newly described $P$. 

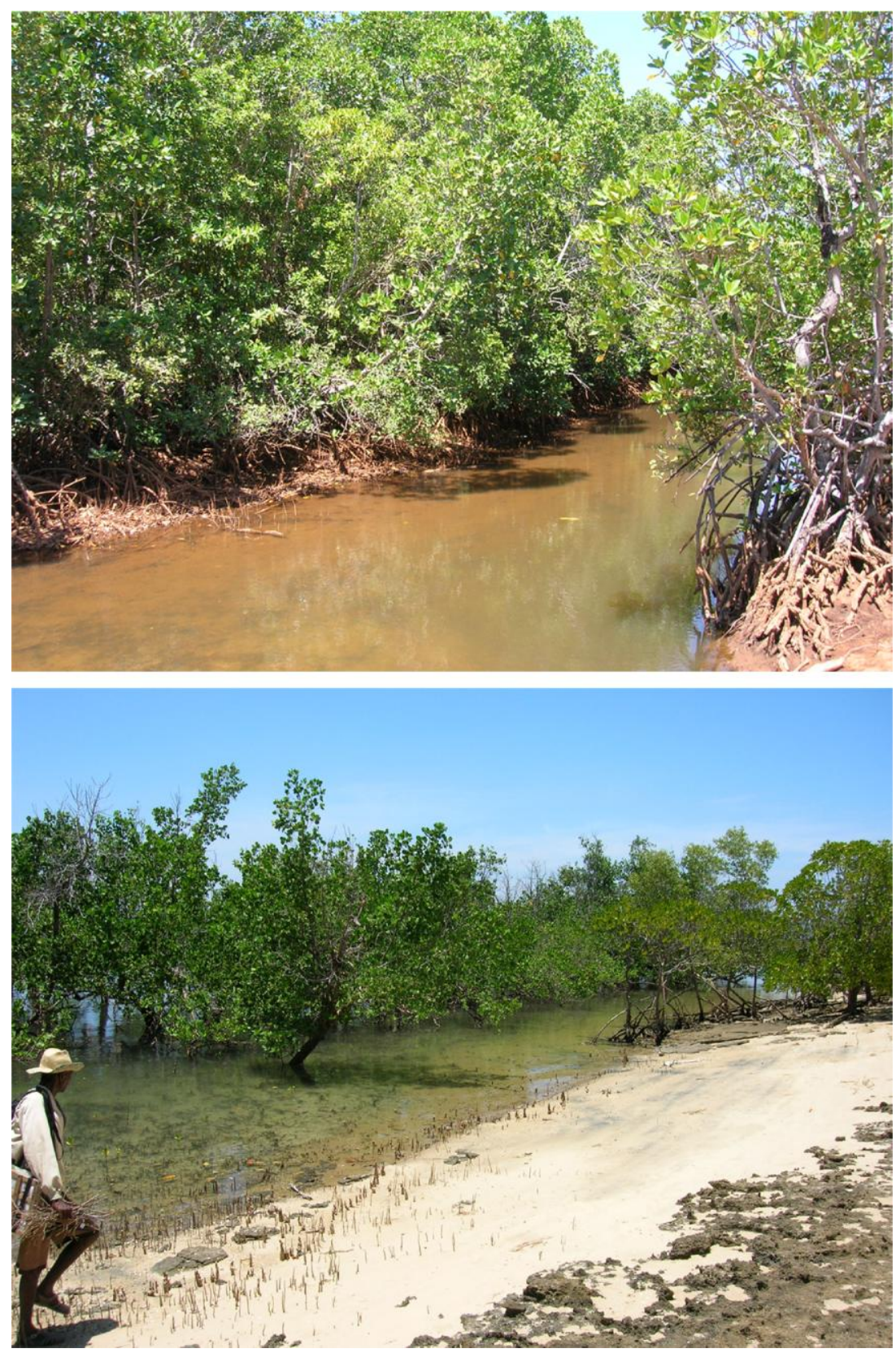

Figs 35-36. Phlebopterum planicapitis sp. n., habitat of the holotype specimen mangrove: Antrema, Mahajanga region (photos by T. BOURGOIN). 

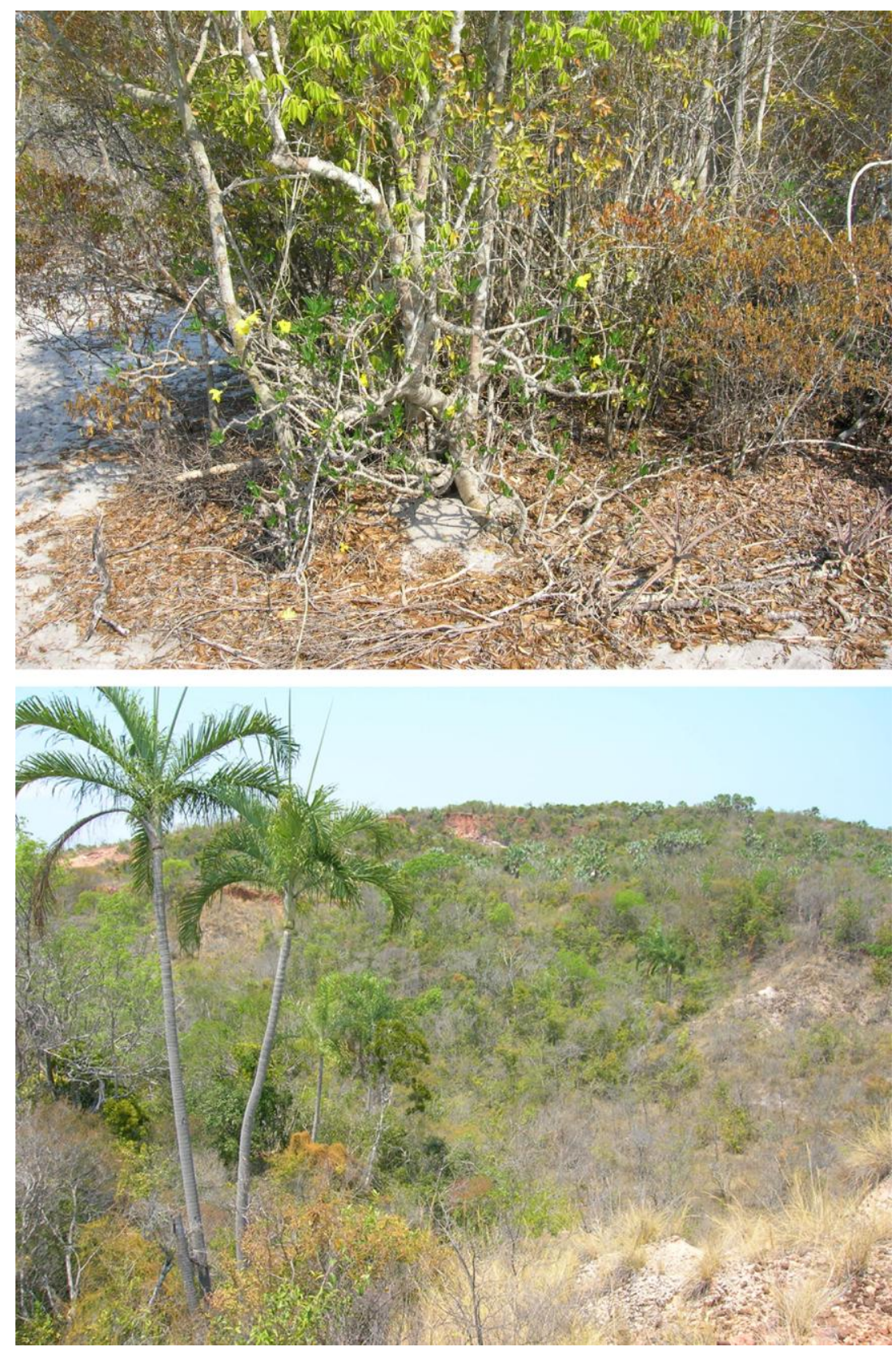

Figs 37-38. Phlebopterum planicapitis sp. n., habitats of the paratype specimens. 37 - forest near Antrema, Mahajanga region; 38 - road leading to the village of Matrobe (photos by T. BOURGOIN). 


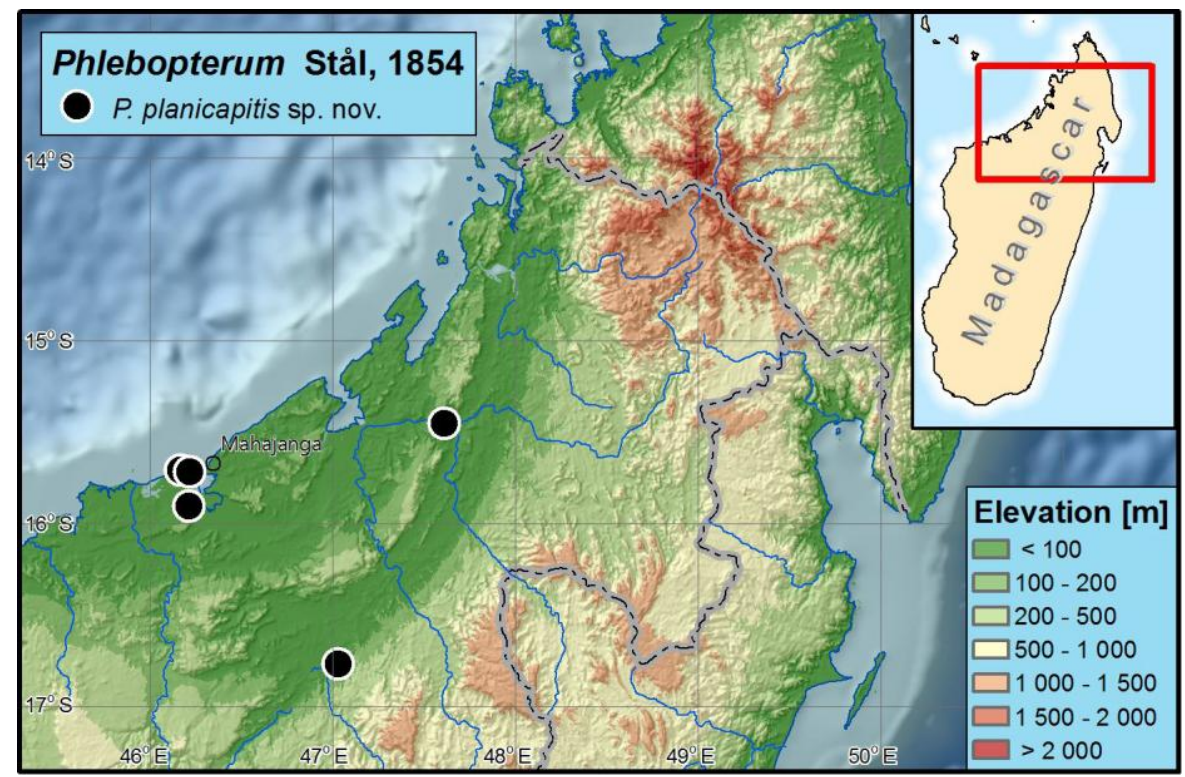

Fig. 39. Phlebopterum planicapitis sp. n., distribution map.

planicapitis is limited to the north-western part of the island, with three localities representing coastal mangroves and another two located far from the coast representing riverside vegetation.

As knowledge of Madagascan and African species of the genus Phlebopterum is still unsatisfactory, further ecological and taxonomic studies are required to explain the relationship between these two groups of taxa.

\section{ACKNOWLEDGEMENTS}

We would like to thank Prof. Thierry BouRgoIN and Dr Norman PenNy for the privilege of studying the flatid material from the entomological collections of the Muséum national d'Histoire naturelle (Paris, France) and the California Academy of Sciences (San Francisco, USA), respectively. 


\section{REFERENCES}

BouRGOIN T. 1988. A new interpretation of the homologies of the Hemiptera male genitalia, illustrated by the Tettigometridae (Hemiptera, Fulgoromorpha). [in:] C. VIDANO, A. ARzONE (eds). $6^{\text {th }}$ Auchenorrhyncha Meeting, Turin, Italy, September 7-11, 1987. CN R-IPRA, Turin, $113-120$.

BourgoIn T. 1993. Female genitalia in Hemiptera Fulgoromorpha, morphological and phylogenetic data. Annales de la Société entomologique de France (N.S.) 29(3): 225-244.

BOURGOIN T. 2017. FLOW (Fulgoromorpha Lists on The Web): a world knowledge base dedicated to Fulgoromorpha. Version 8, updated [2017-04-27]. http://hemiptera-databases.org/flow/

Bourgoin T., HuAng J. 1990. Morphologie compare des genitalia males des Trypetimorphini et remarques phylogénétiques (Hemiptera: Fulgoromorpha: Tropiduchidae). Annales de la Société entomologique de France (N.S.) 26(4): 555-564.

Bourgoin T., Rong-Rong W., Asche M., Hoch H., Soulier-Perkins A., Stroiński A., Yap S., SzWEDO J. 2015. From micropterism to hyperpterism: recognition strategy and standardized homology-driven terminology of the forewing venation patterns in planthoppers (Hemiptera: Fulgoromorpha). Zoomorphology 134(1): 63-77.

CARAYON J. 1969. Emploi du noir chlorazol en anatomie microscopique des insectes. Annales de la Société entomologique de France (N.S.) 5(1): 179-193.

GANZHORn J.U., LOWRY II P.P., SchatZ G.E., SOMMER S. 2001. The biodiversity of Madagascar: one the world's hottest hotspots on its way out. Oryx 35(4): 346-348.

LALLEmand V. 1931. Description de trois nouveaux Homoptères Congolais. Revue de Zoologie et de Botanique Africaines 20: 302-304.

MĄKol J., Moniuszko H., ŚwiercZewski D., StroińSKi A. 2014. Planthopper (Hemiptera: Flatidae) Parasitized by Larval Erythraeid Mite (Trombidiformes: Erythraeidae) - A Description of Two New Species From Western Madagascar. Journal of Insect Science 14(1): 1-12.

McNeely J.A., Miller K.R., Reid W.V., Mittermeier R.A., Werner T.B. 1990. Conserving the World's Biological Diversity. International Union for Conservation of Nature and Natural Resources, World Resources Institute, Conservation International, World Wildlife Fund-US, World Bank, Gland, Switzerland - Washington, D.C.

Melichar L. 1902. Monographie der Acanaloniiden und Flatiden (Homoptera) (Fortsetzung). Annalen des k.k. Naturhistorischen Hofmuseums, Wien 17: 1-253.

Myers N., Mittermeier R.A., Mittermeier C.G., DA Fonseca G.A.B., Kent J. 2000. Biodiversity hotspots for conservation priorities. Nature 403(333): 853-858.

O'BRIEN L. 2002. The Wild Wonderful World of Fulgoromorpha. Denisia (N.F.) 4: 83-102.

SCHMIDT E. 1912. Diagnosen neuer Fulgoriden-Gattungen und Arten nebst einigen Bemerkungen. Stettiner Entomologische Zeitung 73(1): 67-102.

STÅL C. 1854. Nya Hemiptera. Ofversigt af Kongliga Svenska Vetenskaps-Akademiens Förhandlingar, Stockholm 11: 231-235. 
Storey M., Mahoney J. J., Sounders A. D., Duncan R. A., Kelley S. P., Coffin M. F. 1995. Timing of hot spot-related volcanism and the breakup of Madagascar and India. Science 267(5199): 852-855.

StroiŃSKi A., GNEZDilov V., BouRgoin T. 2011. Sub-brachypterous Ricaniidae (Hemiptera: Fulgoromorpha) of Madagascar with morphological notes for these taxa. Zootaxa 3145: 1-70.

ŚwiercZewsKi D., StroińSKI A. 2012. A new species of Phlebopterum STÅL, 1854 (Hemiptera: Fulgoromorpha: Flatidae) from the tapia woodlands of Madagascar. Annales Zoologici 62(4): $577-592$.

STROIŃSKi A., ŚWIERCZEWSKI D. 2014a. Sogalabana ochracea gen. et sp. nov. from Tsaratanana massif in northern Madagascar (Hemiptera: Fulgoromorpha: Flatidae). Journal of Natural History 48(29-30): 1853-1865.

STRoiŃSKi A. , ŚWIERCZEwSKi D. 2014b. Griveaudus gen. nov. (Hemiptera: Fulgoromorpha: Flatidae) from Tsaratanana Massif supports the biodiversity of montane flatids in Madagascar. Zootaxa 3861(1): $61-75$

ŚwierCZEwski D., StroiŃSKi A. 2013. Madagascar Flatidae (Hemiptera, Fulgoromorpha): state-ofthe-art and research challenges. [in:] A.S. Popov, N. Grozeva, E. Simov, X. Tasheva (eds.). Advances in Hemipterology. ZooKeys 319: 293-301.

ŚwiercZewski D., Stroiński A. 2015a. Revision of the endemic genus Perinetella (Hemiptera: Fulgoromorpha: Flatidae) from Madagascar. Acta Entomologica Musei Nationalis Pragae 55(2): $539-558$.

ŚwIERCZEWSKi D., STRoIŃSKI A. 2015b. A new species Flatopsis wojciechowskii from Nosy-Komba and Madagascar (Hemiptera: Fulgoromorpha: Flatidae). Polish Journal of Entomology 84(4): 339-349.

ŚWIERCZEWSKi D., Bourgoin T., STROIŃSKI A. 2016. Revision of the Madagascan genus Paraflata (Hemiptera: Fulgoromorpha: Flatidae) with notes on planthopper hosts parasitized by Epipyropidae moths. Annales Zoologici 66(1): 57-82.

WALKER F. 1851. List of the specimens of Homopterous insects in the collection of the British Museum. Part II. British Museum, London.

Received: 8 May 2017

Accepted: 10 July 2017 